\title{
事例に基づくデザイン支援と評価基盤の構築
}

\section{Design Assistance by Example and Construction of Evaluation Basis}

\author{
片寄 晴弘 \\ Haruhiro Katayose \\ 関西学院大学理工学部, 科学技術振興事業団さきがけ研究 $21 「 十$ 協調と制御」領域 \\ Kwansei Gakuin University, PRESTO/JST \\ katayose@ksc.kwansei.ac.jp, http://www.wakayama-u.ac.jp/ katayose/ \\ $\underset{\text { Keiji Hirata }}{\text { 平圭二 }}$ \\ NTT コミュニケーション科学基礎研究所 \\ NTT Communication Science Laboratories \\ hirata@brl.ntt.co.jp, http://www.brl.ntt.co.jp/people/hirata/ \\ 原田 利宣 \\ Toshinobu Harada \\ 和歌山大学システム工学部 \\ Wakayama University \\ harada@sys.wakayama-u.ac.jp, http://www.wakayama-u.ac.jp/ ${ }^{\text {harada/ }}$ \\ 平賀 瑠美
Rumi Hiraga \\ 文教大学情報学部 \\ Bunkyo University \\ rhiraga@shonan.bunkyo.ac.jp, http://www.bunkyo.ac.jp/〜rhiraga/ \\ 笠尾 敦司 \\ 東京工芸大学芸術学部 \\ Tokyo Institute of Polytechnics \\ kasao@dsn.t-kougei.ac.jp, http://www.dsn.t-kougei.ac.jp/cd_home/
}

keywords: design assistance, case-based reasoning, art, kansei

\section{Summary}

Design is one of the typical tasks which are realized with both intelligence and sense. When demands for contents are increasing in this decade, design assistance with computers is one of the most important information technology services. The design assistance method known as Kansei Engineering, which combines multivariate analysis of impression and media technology, is not always applicable to productive design tasks. In the practical productive design, concrete cases are sometimes picked up in advance of design processing. This paper, focusing on this design, describes the style of case-based design, assistance by computers, the range of application, and the evaluation of generated contents.

\section{1.は じめに}

デザインとは, 知性と感性が同時に表出される最も典 型的なタスクの一つである .コンテンツニーズが高まっ ている現在 , デザイン支援は最も必要とされる情報処理 技術の一つに位置づけられる .

本稿では, 表現の目標があって，兴れを具体化するプ ロセスまたは光の結果を，デザインと呼ぶことにする*1． プロダクトデザインやコンテンツの制作における商業的 なデザインの多くはこの範疇に属するものと考えられる . また，表現自体を主体とするアートの世界でも，ここで いうデザインが , 作品の中で重要な位置をしめているこ とはいうまでもない*2

デザイン支援に関する代表的なアプローチとしては ,デ

*1 デザインの評価と繰り返しによって，当初目標が修正された り，目標が明確化されるといったことがある

$* 2$ 一般的には, 表現者の問題意識を作品という表現行為で表 象したものをアート,与えられた問題意識を, 分類学 , テクノ ロジー，インタフェースによって解決を図った表現行為をデザ インと，定義することが多い，我々のデザインの定義は，アー ティファクトへの具体化の部分に,より留意したものとなって いる.コンセプトが優れていてもデザイン，すなわち，詰めが 甘い場合，作品の完成度は低くなってしまう。
ザイン素材の印象の多変量解析とメディア提示技術を組 みあわせたものが知られており，感性工学として，さまざ まな応用システムが作られてきた [長町 93, 大澤 00] .こ の手法は , 商品群の中からイメージに合ったものを探す といった検索型のタスクに対しては有効である反面，イ メージ空間設定の煩杂隹さ, 印象空間上での分解能の問題 から，生成系のデザインプロセスを支援する目的には必 ずしも実利用されてこなかった [片寄 00].

プラニング, デザインの初期段階においては，インタ フェースとして形容詞が用いられることもあるが，実際 にデザインを行う段階においては, 具体的な目標事例を 設定し，弚のイメージを再現するといったアプローチが 取られることが多い. 本稿では, 音楽, 絵画, 造形分野に おける，この種のデザインプロセスを取り上げ，光の特 質，計算機での支援，応用性，評価について論じていく．

\section{2. 事例に基づくデザイン}

本章では，事例によるデザインと言語情報によるデザ インについて比較する . 事例に基づくデザイン支援の形 
について，簡単に整理する。

\section{$2 \cdot 1$ 事例と 言語情報}

映画「ゴーストバスターズ」のテーマソングが , ヒュー イ・ルイス\&ニューズ の゙ I Want a New Drug”にあ まりにも似ていると騒ぎになったことがある . テーマソ ングの作曲者，レイ・パーカー Jr. か謝罪して一件落着 となったが，監督のアイバン・ライトマンが，レイに I Want a New Drug” のような曲を作って欲しいと頼ん だのがことの始まりだと言われている .

自分の所望のデザインを言葉で伝えるのは容易なこと ではない．上記の例では著作権が問題となったが , 形容 詞を用いて意図を伝えるより，例えば，編曲はビートル ズ風にするとか , ゴッホの自画像のタッチを使うなどと いうように具体的な事例を示した方が，はるかにイメー ジを伝えやすい .

映画やゲームなどのコンテンツにおいては , 全体のイ メージの方向性が予め決まっている．关こに使われる映 像エフェクトや音楽などの素材は全体のイメージに沿っ た形のものが選ばれる . 大量消費のデザイン*3において は, 視聴者 , 鑑賞者がどのように受け止めるかが明確に 意識されており，明文化されていないにしても規範が存 在する．弚の上で，具体的な事例を掲げてから制作が開 始されることが少なくない．通常，このような形でのデ ザインは，専門家に依頼して実施される．

今回，主題とするのは，このような制作プロセスを支 援・代替する手段であり，事例となる作品や素材の特徵の 記述と把握，デザインの転写方式を検討対象としている．

事例に基づいてデザインを行う時には , デザインを企 図する者が, 前もって所望のデザインを知っている必要 がある．この点で，形容詞を用いた検索に比べて，煩雑 と思われるかもしれないが , 制作に使われる典型的なデ ザイン事例の数は限られている .メディア提示機能を用 意しておけば，直接的な参照が可能であり，言語情報を 用いるのと比べて，大きな負荷にはならない．

より具体的，あるいは，特殊なデザインを再利用した い時には, 事例によるデザイン支援のメリットを最大限 活かすことができる . 経験の中で , 印象に残る素材があ れば, 乥れを集積しておいて, 必要に応じ引きだすこと でデザインの再利用が可能となる．インターネットの利 用形態が多樣化する現在, Semantic Web[浦本 01] やア ノテーション [Kahn 01] の技術を用いてデザイン事例や 関連情報等を機械処理可能とすることで，有機的に結合 したデザイン知識を効率的に集積・再利用することが期 待される．

$* 3$ ノーマンは, デザインに対し, 誰もが誤解しないインタフェー スを提供することを求めている [Norman 90].

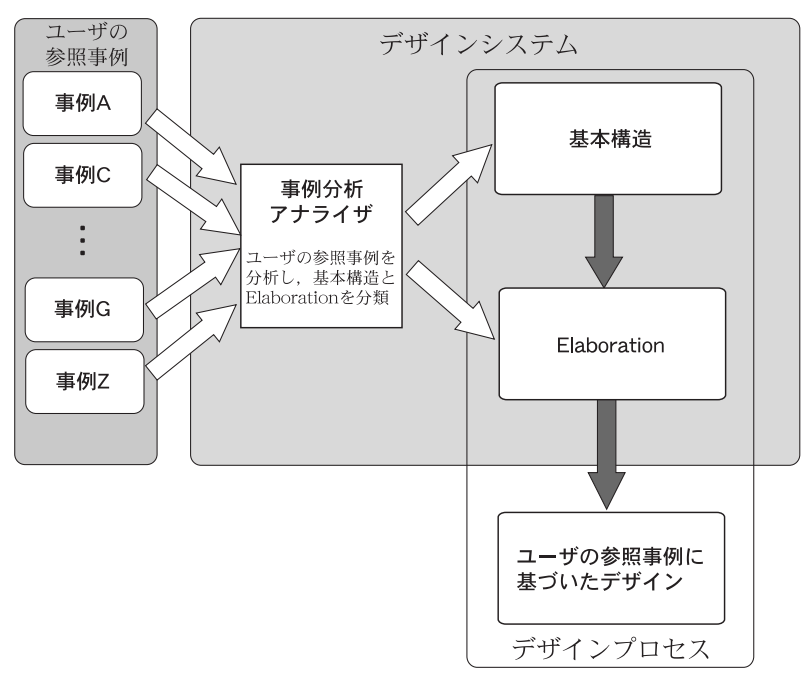

図 1 デザインの再利用・転写の概念図

\section{$2 \cdot 2$ デザインの基本構造と Elaboration}

通常 ,デザインは, 基本構造 (骨格部分) と Elaboration (デザインの具体化, 詳細化部分) に分けることが出来る . デザインの再利用・転写を実現するには，事例の基本構 造と Elaboration (デザインの具体化, 詳細化部分) を分 離，記述することが中心的な技術の一つとなる．この実 現にはパターン認識技術を核として用いることが期待さ れる.パターン認識は, 複数のパターンにおける共通要 素に着目し，適当な規準で判別を行う技術である [片寄 90, 田中 99] . 従来のパターン認識では, Elaboration の 部分は, 不必要な部分として切り捨てられてきたが, 基 本構造と Elaboration の付加文法を検討していくことで， デザイン転写の基礎的なフレームワークを作成すること が可能となる .

\section{$2 \cdot 3$ デザインの再利用・転写システム}

事例の基本構造と Elaboration の分離が出来た段階で は,さまざまなデザイン支援の形が考えられる(図 1).最 も基本的なものとしては, ユーザが基本構造 (モチーフ) を用意し，他のデザイン事例の Elaboration をコピーす るといったタイプが考えられる [平田 01] . モチーフ自体 を他の事例から抽出するということも可能だし，複数の 事例からの平均的な Elaboration を用いることもできよ う.さらに，Elaboration を plug in 方式*4で適用する デザイン支援の形も想定される .

\section{3. 経 緯}

筆者らは光れ光れ音楽，絵画，造形の領域において， 事例に基づくデザイン支援に関する研究を実施してきた . その中で, 共通の課題を認識したことが近末来チャレン

*4 Elaboration に階層的あるいは独立成分として分離できるタ イプのものがある . 
ジにおける提案のきっかけとなっている . 以下に各領域 での経過と課題を簡単に紹介する。

\section{$3 \cdot 1$ パフォーマンスレンダリング}

パフォーマンスレンダリングとは音楽演奏における表 情付けを意味する . 1980 年代には , ルールベースによる 表情付けシステムの研究が始まり，1990 年代には，演奏 ルールの学習を行うシステムが発表されるようになった . これらのシステムが発表された当初は感性領域でのタス クを実現する研究例として，非常に大きな関心を集めた が , 人間の初心者の稚拙さとは異なった「不自然さ」が 指摘されるようになった 。

「不自然さ」の最も大きな理由の一つとしては，単純 に演奏記号や表層的な音の並びに対して演奏表現を与え ようとしたことが上げられる．最近では，音楽の構造認 知モデルをベースとし，音楽の基本構造と実際の音の並 び，さらに光れらと具体的な演奏の関連として，演奏表 現をとらえようとする段階にあり，システムの生成演奏 の質も向上してきた . まだまだ人間の名演奏家には及ば ないが , パフォーマンスレンダリングは, 解釈のプロセ スに焦点をあて，演奏の質を向上させるといった点に興 味の中心か移りつつある .

この段階になると，実験例として提示された楽曲も手 法も異なるシステムをどのように評価していけばよいの か，というパラダイムが意識されるようになった．关の 方策の一つとして , 計算機による演奏コンクールの実施 の準備が進んでいる [平賀 02] . 2002 年 7 月に開催された ICAD(International Conference on Auditory Display) に併設する形で開催された第一回目のワークショップで は , パフォーマンスレンダリングに関する世界のシステ 么生成演奏が一堂に集められ，聞き比べが行われた .

学習や事例べース推論などの機能を持ったシステムに とっては，提示された演奏樣式の再現性を審査するなど の手法により，主観判断の影響を軽減した上での評価が 可能である.

我々は，審査項目と炎の基準を明確にするという試み のもとに, 特徵的な演奏表現を取り出して部分審査を行 なったり，初演演奏を競い合うなど新しい形の音楽コン クールを目指している．コンクールの詳細情報，演奏生 成例については，URL ${ }^{* 5}$ から入手可能である．

\section{$3 \cdot 2$ 絵画制作支援}

この節では，アルゴリズミックに制作される CG 絵画 の研究に触れるが, 絵画の基本構造となる対象や構図な どについて，実用レベルでの解析はまだできていない． 弚の意味において, まず, 基本構造, Elaboration をど のように定義・分離するかという問題が存在する . 以下， オープンソースにすることを目的に開発を進めている絵

*5 http://shouchan.ei.tuat.ac.jp/ rencon/

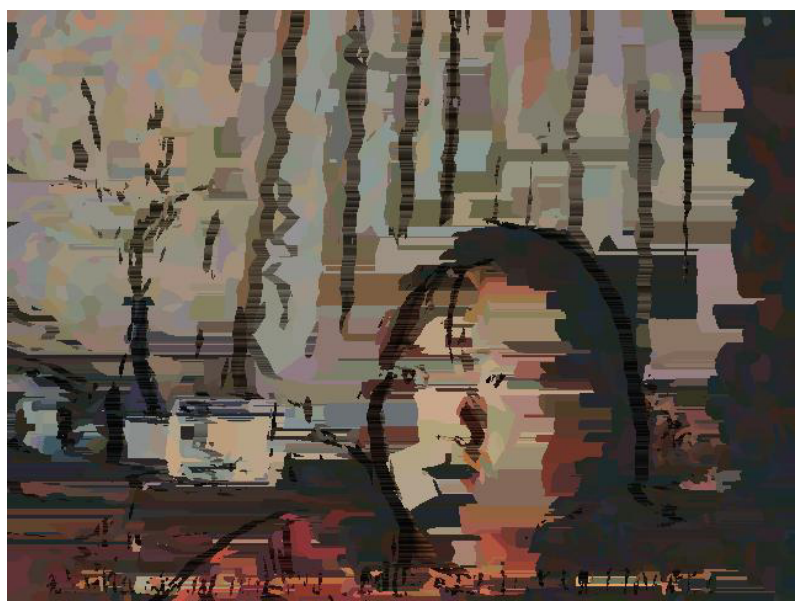

図 2 SIC による作品例

画制作ソフトを利用した研究 [笠尾 01] を紹介すること で，絵画領域における基本構造，Elaboration の捉え方 と，デザイン支援に迫りたい．

SIC(Synergistic Image Creator) ${ }^{* 6}$ を用いれば，用途 は限定されるものの, かなり高度な作品を作り出すことが 可能である.図 2 にこのソフトで制作した作品例を示す．

SIC の設計方針は , 人間が見ている対象を入力画像と し，弚れをもとに制作された絵画を出力作品として，光 の変換過程において画家の頭の中でなされる画像変換プ ロセスをコンピュータで実行可能なアルゴリズムに置き 換えるというものである. 最終的な目標達成 への道程 は長いが, 現状で得られた成果をまとめたものが公開中 の SIC である . SIC は単純に画像の表層のみ絵画に似せ るのではなく，画像を一度解析し，光の結果をべクトル データにまとめ上げ，光れをもとにレンダリングすると いうプロセスを持っている．この特徵により，少量のパ ラメータの変更で, 多樣な表現を生み出すことが可能と なっている .

SIC は他のレンダリングソフトとは異なり，基本的な プロセスを変えることなく多樣な表現を生み出せるアル ゴリズミックな絵画制作ソフトである．一つの絵画を制 作するまでに必要な処理が確定されると，乥れをまとめ てーつのスクリプトとして記録することができる．つま り，一つのスクリプトを一つの絵画制作事例と考えるこ とができる .

スクリプトと光れによって制作された CG 絵画作品と 弚のもとになった画像のセット (これを CG 絵画スクリ プトセットと呼ぶことにする) を多数用意しておくこと で，CG 絵画スクリプトセットを絵画制作事例としたオ リジナルな $\mathrm{CG}$ 絵画を制作するシステムを構築すること ができる .

このシステムの使用例は以下のようになる . 例えば風 景などの写真画像に合わせて，オリジナルの画風で CG 
絵画の作品を作りたいと思った場合，まず，CG 絵画ス クリプトセットの作品例を検索し，好みに一番近いもの を見つけだす．光して，弚の作品を作り出したスクリプ 卜を自分が気に入るように改良し，より好みに合った作 品を作り出せるオリジナルのスクリプトを作る．最後に， ぞのスクリプトを写真画像に適用することでオリジナル 作品を作り出す．作り出されたスクリプトを $\mathrm{CG}$ 絵画ス クリプトセットに加えられる樣にすれば，自動的に作例が 増え続けるような絵画制作システムを作ることもできる． 絵画制作にむけての初期的な主要課題は，

(1) web から本システムを利用でき，作り出された新 たなスクリプトも事例に登録可能な環境の構築

(2) 質の高い作品を作り出せるようにするため, スク

リプトの利用や制作に関する知識の整理と提供 の 2 つである.アルゴリズミックに絵画を制作すると，今 までにない新しい表現が多数作り出される可能性がある. 兴のため，今まで作られてきた従来の優秀な作品を基準 にして新たな作品の善し悪しを判断することは困難であ るし，あまり意味がない，しかし，既にある表現に似た ものや，人間にとってノイズと区別の付かない画像や単 色で塗りつぶされたような画像は, 誰にとっても意味が 薄いであろうから，大まかな判断基準をまず作り，光こ から先は画像利用の目的志向で画像を選別する必要が出 てくるものと考えている .

\section{$3 \cdot 3$ 造 形 支援}

造形や映像の世界では, 基本構造と Elaboration を構 成する単位となる視覚言語の抽出研究力関心を集めてい る、視覚言語とは，G．ケペッシュによって1944 年に乥

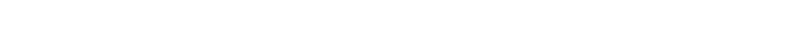
真，映画，テレビなどの映像は, 音声と文字を通じて意 味内容を伝達するための通常の言語と同樣に視覚に訴え る造形要素をもとにした，ひとつの “言語” としてとら えよう」とする考え方である．建築の分野で最も視覚言 語の概念に近いものとして，C.アレグサンダーの提案 する “パタン・ランゲージ”がある . “パタン・ランゲー ジ”とは，建築計画におけるいろいろな機能で分類した 構成要素 (広場, 居間, 寝室など) である．C.アレグサ ンダーは,これら゙ パタン・ランゲージ”を定性的, 経験 的に抽出し，ネットワークて結ぶことにより" パタン・ ランゲージ”を体系化した．造形の世界においても，以 前から多くの視覚言語抽出研究がある.しかし, これら 多くの視覚言語抽出研究は, 造形研究家や建築家の直感 によるものがほとんどであり，一般性，客観性に欠ける .

乥こで, 原田らは自動車デザイン (コンフィグレーショ ン, 面構造, 曲線 (面)) をケーススタディにして, 弚の 物理量の定量化や認知科学的アプローチにより視覚言語 抽出を行った [原田 98] . 具体的には, 下記の4つの研究 段階から構成されている.

（1）デザイン対象のデザインプロセスを明らかにし，

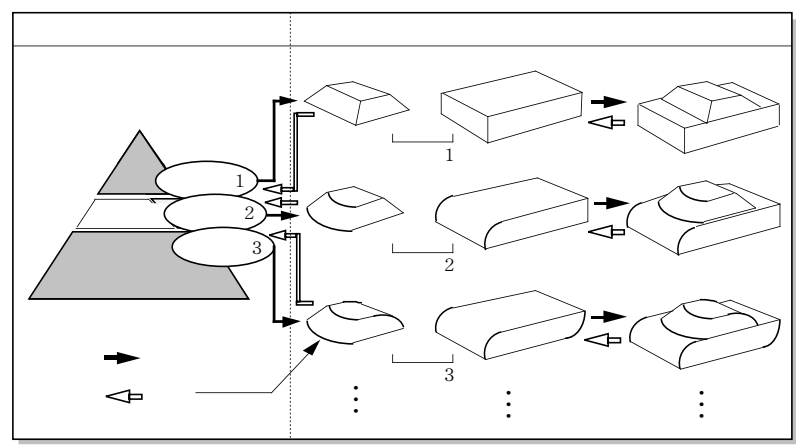

図 3 視覚言語と構造

弚こでデザイナに与えられたり，デザイナが創出す る目標概念 (イメージ) を抽出・体系化した .

(2) 各デザインプロセスにおいて , デザイナがデザイ ン作業でどのような視覚言語を用いているのか調査 した．また，可能な限り光れらを定量的に分類・体 系化できる方法を考案した .

(3) 抽出 (創出) された視覚言語を組合せることによ り，どの程度の範囲のデザインが創成可能になるの か, 弚の解空間全体を認識した .

（4）抽出された概念と視覚言語，さらに光れら視覚言 語をどのように組み合わせるのかという統語法との 関係をモデル化，検証した .

デザインとは,イメージを具現化する視覚言語を探索 し，光れを統語することであり，これは逆推論問題を解 くことになる．また，目標事例からイメージを導き出す ことは順推論となり，一般的に容易である.しかし，光の 推論途中段階の視覚言語と統語法の理解なくしては, 真 の意味でのデザインの再利用はできない (図 3) .つま り，これら客観性のある視覚言語を抽出して，初めて目 標事例を基本構造と Elaboration に分離でき，光れ光れ の目標概念 (イメージ) に対する役割を知ることができ るだろう．さらには，目標事例を表層に捕らわれず解釈 し，弚の本質的な部分を読みとりデザインの再利用・転 写することがチャレンジ課題となる .

\section{4. まとめと 展 望}

本提案では，コンテンツならびに弚の素材の制作を目 的としたデザイン支援として，事例を利用したデザイン について述べてきた .デザインの基本構造 , Elaboration の分離，活用という一般的な概念を示した .

現時点で本チャレンジを実現するための網羅的な方法 論は確立されていない，しかしながら，技術的には，パ ターン認識，事例に基づく推論，データマイニングなど 人工知能の中心的な成果に立脚しており，十分な実現可 能性が見込めると考えている .

3.1 節では, 音楽の中で, 特にパフォーマンスレンダ リングについて事例を用いたデザイン支援について紹介 
した .これ以外にも音楽分野では，データベースを用い た作曲システムが存在する [Cope 91] . いずれの対象で も, 音楽認知の計算モデルの構築, 評価, という問題が 存在する. 乥こで, 主観領域での評価の一つとして，コ ンクール開催にむけての試みに触れた .

3.2 節では, 絵画におけるデザイン支援について述べ た .ここでは，スクリプトセットという考え方を示した . モジュール化を前提としたアプローチにおいては , デザ イン支援において事例を追加することが重要となる．デ ザイン領域におけるモジュール化という問題についても 取り組む必要があるだろう。

音楽, 絵画, 造形の各領域において, 基本構造と Elaboration の分離，コミュニティを意識した評価実験が開始 されている .ここで, 領域は異なるものの, 問題意識, 解 決の手法については多くの共通事項が存在することを確 認している．デザインという作業には主観的で暗黙的な 側面があり，またデザインの対象となるコンテンツにも 曖昧な側面がある．これらを機械的に処理する時，ユ一 ザによる評価や価値観をどう反映するかが必ず問題とな る.これは, 個人デザイン , グループデザインが生み出し た基本構造と Elaboration に対し，コミュニティ全体に 関し安定かつ一貫した意味付けをいかに行うかというこ とである . あるいは, 個々のユーザの評価や価值観をコ ミュニティ全体のどニに位置付けるのかと換言すること もできよう.ここで, 2.1 節で述べた Semantic Webや アノテーションの上に Public Opinion Channel (POC) のような機構を導入することで，コミュニティ全体の意 見を参照し，対する個々のユーザの嗜好や主観を相対化 することができるのではないかと期待している．今後は， これらの成果を足がかりに，絵画，アニメーション，音 楽, ダンス, モーション等, メディア横断的にデザイン 支援技術を広く探求していきたい。

\section{$\diamond$ 参 考 文 献 $\diamond$}

[Cope 91] David Cope, Computers and Music Style. Madison, WI: A-R Editions (1991).

[原田 98] 原田利宣, 森山真光, 吉本富士市: 視覚言語を用いた 曲線創成システム, デザイン学研究, Vol.45, No. 3, pp.63-70 (1998).

[平賀 02] 平賀瑠美, 平田圭二, 片寄晴弘: 蓮根 : 目指せ世界一の ピアニスト, 情報処理, Vol.43, No.2, pp. 136-141 (2002).

[平田 01] 平田圭二, 平賀 瑠美: 2 段階演奏表情付け法によるイ ンクリメンタルな演奏生成システム, 情報処理学会 音楽情報研, 2001-MUS-39, pp.19-26 (2001).

[Kahn 01] Jose Kahn and Marja-Riitta Koivunen: Annotea: An Open RDF Infrastructure for Shared Web Annotations, ACM WWW10 (2001).

[笠尾 01] 笠尾敦司： Linux GIMP のプラグイン: SIC で 目指す芸術と科学の融合-数行のプログラムの変更がもた らす個性的な CG 表現の世界- Linux Conference 2001, http://lc.linux.or.jp/lc2001/papers/linux-sic-paper.pdf (2001).

[片寄 90] 片寄晴弘, 井口征士 : 知的採譜システム, 人工知能学 会誌, Vol.5, No.1, pp.59-66 (1990).

[片寄 00] 片寄晴弘 (和歌山大学デザイン情報学科編)：デザイ
ンと情報処理, デザイン情報学入門, pp.161-183 (財) 日本規格 協会 $(2000)$

[長町 93] 長町三生編: 感性商品学: 感性工学の基礎と応用, 海文 堂出版 (1993).

[Norman 90] D.A. ノーマン著, 野島久雄訳: 誰のためのデザイ ン? 新曜社認知科学選書 (1990).

[大澤 00] 大澤 光編: 印象の工学とは何か, 丸善 (2000).

[田中 99] 田中昭二, 井口征士, 岩舘祐一, 中津良平: 画像領域の 色およびテクスチャのコントラストを特徵量とした図領域の抽 出, 情報処理学会論文誌, Vol.40, No.8, pp.3267-3280 (1999).

[浦本 01] 浦本直彦: Semantic Web - 機械のための Web, 人工 知能学会誌, Vol.16, No.3, pp.412-419 (2001).

\section{〔担当委員 : 津本周作〕}

2002 年 8 月 15 日 受理

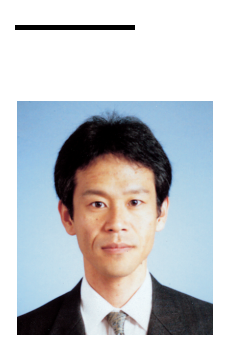

者 紹 介

\section{片寄 晴弘(正会員)}

1991 年大阪大学大学院基礎工学研究科制御工学分野卒業。 工学博士. 1997 年より, 和歌山大学システム工学部助教 授. 2002 年より, 関西学院大学助教授. 音楽情報処理, 感 性情報処理，インタラクティブアート制作の研究に従事。 1990 年情報処理学会学術奨励賞受賞. 情報処理学会, 電 子情報通信学会, ICMA 各会員. 1998 2002 年情報処 理学会論文誌編集委員 . 科学技術振興事業団さきがけ 21 研究員.

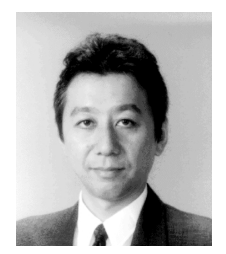

平田 圭二(正会員)

1987 年 東京大学大学院 工学系研究科情報工学専門課程博 士課程修了. 工学博士. 同年 NTT 基礎研究所. 1990-93 年 (財) 新世代コンピュータ技術開発機構 (ICOT). 日本ソ フトウェア科学会 第 3 回大会 高橋奨励賞 (1987). 情報処 理学会 論文賞 (2002). 情報処理学会, 日本ソフトウェア科 学会, International Computer Music Association 各会員

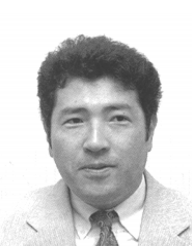

原田 利宣(正会員)

1996 年千葉大学大学院自然科学研究科デザイン科学研究 分野修了。工学 (博士) 、マツダ (株), 日産自動車 (株) を経て，1997 年度より，和歌山大学システム工学部デザ イン情報学科助教授. 1996 年日本デザイン学会研究奖励 賞受賞. 日本デザイン学会, 情報処理学会会員, 感性工学 会各会員

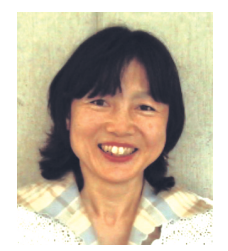

\section{平賀 瑠美(正会員)}

東京大学理学部情報科学科卒業, 筑波大学理工学研究科. 工 学研究科修了. 日本 IBM 株式会社東京基礎研究所, IBM アルマデン研究所勤務. 現在, 文教大学情報学部助教授 博士 (工学) . $\mathrm{ACM}$, 情報処理学会, 日本ソフトウェア 科学会, ICMA 各会員.

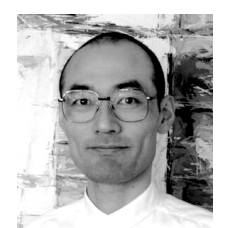

\section{笠尾 敦司}

1986 年東京工業大学総合理工学研究科博士前期課程修了。 博士 (工学) .平成 10 年度より, 東京工芸大学芸術学部溝師。 平成 12 年度より, 同大学助教授. 視覚情報処理と情報デ ザインの研究に従事.2001 年 Linux Conference 2001 最優秀プレゼンテーション賞受賞 . SIGGRAPH2002 ArtGallery 入選 。情報処理学会, IEEE，ACM，デザ イン学会, 絵本学会各会員. 